\title{
Uji Efektivitas Antibakteri Sediaan Krim Ekstrak Etanol Daun Kaliandra (Calliandra surinamensis) Terhadap Bakteri Staphylococcus aureus
}

\author{
Gichella C.J Somba*,Hosea Jaya Edy*,Jainer Pasca Siampa* \\ Program Studi Farmasi, FMIPA, Universiitas Sam Ratulangi Manado, Indonesia
}

\begin{tabular}{|c|c|}
\hline KATA KUNCI & A B S TR A K \\
\hline $\begin{array}{l}\text { Daun Kaliandra } \\
\text { Krim } \\
\text { Antibakteri } \\
\text { Staphylococcus aureus }\end{array}$ & $\begin{array}{l}\text { Daun Kaliandra (Calliandra surinamensis) mengandung senyawa } \\
\text { flavonoid, saponin dan tannin yang mampu menghambat pertumbuhan } \\
\text { bakteri. Penelitian ini bertujuan untuk memformulasi dan mengetahui } \\
\text { efektivitas antibakteri sediaan krim ekstrak etanol daun Kaliandra } \\
\text { terhadap bakteri Staphylococcus aureus. Penelitian ini menggunakan } \\
\text { metode eksperimental laboratorium. Formula sediaan krim dibuat } \\
\text { dengan variasi konsentrasi ekstrak etanol daun Kaliandra } 2 \%, 3 \%, 4 \% \text {, } \\
5 \% \text {, } 6 \% \text {. Ekstrak daun Kaliandra diperoleh dengan cara maserasi } \\
\text { menggunakan pelarut etanol } 96 \% \text {. Penelitian uji antibakteri sediaan } \\
\text { krim esktrak etanol daun Kaliandra menggunakan metode sumuran } \\
\text { pada bakteri Staphylococcus aures menghasilkan daya hambat yang } \\
\text { terbesar } 5,09 \pm 0,88 \text { mm pada konsentrasi } 6 \% \text {. Dapat disimpulkan } \\
\text { bahwa sediaan krim ekstrak etanol daun Kaliandra memiliki efektivitas } \\
\text { antibakteri yang sedang }\end{array}$ \\
\hline
\end{tabular}

K E Y W O R D

Kaliandra Leaf

Cream

Antibacterial

Staphylococcus aureus

\begin{abstract}
A B S T R A C T
Kaliandra leaf (Calliandra surinamensis) contains flavonoid compounds, saponins and tannins that can inhibit bacterial growth. The aim of this study was to formulate and investigate the antibacterial effectiveness of Kaliandra leaf ethanol extract cream against Staphylococcus aureus. This research uses laboratory experimental methods. Cream preparation formula is made with variations in the concentration of ethanol extract of Kaliandra leaves 2\%, 3\%, 4\%, 5\%, 6\%. Kaliandra leaf extract was obtained by maceration using $96 \%$ ethanol solvent. The antibacterial test study of ethanol extract of Kaliandra leaf extract using the method of Staphylococcus aures produced the greatest inhibition of $5.09 \pm 0.88 \mathrm{~mm}$ at a concentration of $6 \%$. It can be concluded that the ethanol extract of Kaliandra leaf cream has moderate antibacterial effectiveness
\end{abstract}

\begin{tabular}{l}
\hline TERSEDIA ONLINE \\
\hline 31 Oktober 2019 \\
\hline
\end{tabular}

\section{Pendahuluan}

Salah satu penyebab penyakit infeksi adalah bakteri (Radji, 2011). Ada beberapa jenis bakteri dan jamur patogen yang mampu bereproduksi untuk menginfeksi manusia. Staphylococcus aureus, Streptococcus pyrogens, Pseudomonas aeruginosa, Candida albicans, dan Microsporum, merupakan beberapa contoh mikroba patogen yang menyebabkan infeksi pada kulit. Penyakit infeksi kulit yang disebabkan oleh Staphylococcus aureus, Streptococcus pyrogens seperti selulit, erisipelas, impetigo, folikulitis, furunkel, karbunkel (bisul) (Leboffe dan Pierre, 2011).

Staphylococcus aureus merupakan patogen pada manusia yang dapat menyebabkan timbulnya penyakit dengan tanda-tanda yang khas, yaitu peradangan, nekrosis dan pembentukan abses yang umumnya bersifat sporadic. Infeksi yang dapat di timbulkannya seperti jerawat atau abses, keracunan

*Corresponding author: Program Studi Farmasi, FMIPA, Universitas Sam Ratulangi, Manado;

Email address: gichellacarolina@gmail.com

Published by FMIPA UNSRAT (2019) 
makanan, endocarditis dan infeksi paru-paru. (Jawetz, dkk., 2001).

Pemanfaatan bahan alami sebagai zat aktif obat sekarang kembali digalakkan dan mulai dikembangkan. Teknologi yang ada dimanfaatkan guna menghasilkan sediaan farmasi yang lebih aman dan efektif dalam proses pengobatan. Zat aktif obat dalam teknologi farmasi mulai memanfaatkan sumber sumber alami seperti tanaman berkhasiat obat (Edy, dkk, 2016).

Salah satu tanaman yang memiliki potensi untuk dikembangkan sebagai antibakteri adalah daun Kaliandra (Calliandra surinamensis). Daun Kaliandra mengandung senyawa kimia saponin, flavonoid, tannin yang mampu menghambat pertumbuhan bakteri Staphylococcus aureus.

Krim merupakan sediaan setengah padat yang digunakan untuk kulit dan bertujuan untuk pemakaian luar yang cocok untuk pengobatan infeksi pada kulit. Sediaan krim yang dimaksudkan memiliki sifat yang tidak lengket, mudah menyebar rata di permukaan kulit berkhasiat sebagai antibakteri merupakan sediaan yang absorbsi bahan aktifnya dari luar kulit ke posisi bawah kulit tercakup masuk ke dalam aliran darah yang disebut sebagai absorbsi perkutan, membawa bahan obat melalui kulit dan tingkat penembusan obat pada kulit lebih cepat dibandingkan dengan pembawa farmasetika tidak dapat jauh menembus kulit (Ansel, 2008).

\section{Material dan Metode \\ Alat}

Alat yang digunakan dalam penelitian ini ialah alat-alat gelas (Iwaki ST Pyrex ${ }^{\circledR}$ ), timbangan digital (AE Adam ${ }^{\circledR}$ ), hotplate magnetic stirrer (Nesco ${ }^{\circledR}$ Lab), mikropipet, $\mathrm{pH}$ meter, oven, autoklaf $\left(\mathrm{ALP}^{\circledR}\right)$, inkubator $\left(\right.$ Ecocell $\left.{ }^{\circledR}\right)$, bacteri coloni counter (Health ${ }^{\circledR}$ ), blender (Miyako ${ }^{\circledR}$ ), penggaris berskala, jangka sorong, wadah krim, lemari pendingin, ayakan 60 mesh.

\section{Bahan}

Bahan yang digunakan dalam penelitian ini ialah daun Kaliandra (Calliandra surinamensis), Etanol 96\%, Ekstrak daun Kaliandra, Setil Alkohol, Gliserin, TEA (Triethanolamin), Parafin Cair, Asam Stearat, Aquadest, Nutrien Agar, krim gentamicin, $\mathrm{Nacl} \quad 0.9 \%$ larutan Mc Farland, Bakteri Staphylococcus aureus, Krim Gentamicin.

\section{Preparasi dan Ekstraksi}

Daun Kaliandra dipanen dari Kelurahan TaraTara, Kecamatan Tomohon Utara, kota Tomohon. Daun yang diambil sebagai sampel adalah keseluruhan dari Daun Kaliandra yang masih dalam keadaan yang baik. Daun Kaliandra segar diambil sebanyak 1,5 kg. Kemudian sampel disortasi dengan tujuan untuk memisahkan kotoran-kotoran atau bahan-bahan asing lainnya dari bahan simplisia. Selanjutnya dicuci hingga bersih pada air mengalir, lalu daun ditiriskan. Sampel kemudian dirajang selama 3 hari untuk mempermudah proses pengeringan. Pengeringan sampel dikeringkan didalam oven dengan suhu $60^{\circ} \mathrm{C}$. Sampel yang sudah kering dihaluskan menggunakan blender menjadi serbuk yang kasar. Serbuk yang dihasilkan diayak dengan ayakan 60 mesh, hingga diperoleh serbuk yang halus. Proses ekstraksi menggunakan metode maserasi yang dilakukan terhadap $400 \mathrm{~g}$ serbuk menggunakan 1,5 L etanol (1:4) selama $3 \times 24$ jam. Filtrat diperoleh melalui penyaringan lalu diuapkan didalam oven sehingga diperoleh ekstrak kental lalu di timbang.

\section{Formulasi Krim}

Formulasi krim di buat dengan berbagai variasi konsentrasi, yaitu 2\%, 3\%, 4\%, 5\%, 6\%. Bahanbahan yang ada dapat di lihat pada tabel 1 .

Tabel 1. Formulasi krim antibakteri

\begin{tabular}{clccccc}
\hline No & Nama Bahan & \multicolumn{5}{c}{ Formula (\% b/v) } \\
\cline { 3 - 7 } . & & F1 & F2 & F3 & F4 & F5 \\
\hline 1. & Ekstrak Daun & 2 & 3 & 4 & 5 & 6 \\
& Kaliandra & & & & & \\
2. & Asam Stearat & 16 & 16 & 16 & 16 & 16 \\
3. & Setil Alkohol & 2 & 2 & 2 & 2 & 2 \\
4. & Gliserin & 8,5 & 8,5 & 8,5 & 8,5 & 8,5 \\
5. & TEA & 7 & 7 & 7 & 7 & 7 \\
6. & Parafin Cair & 10 & 10 & 10 & 10 & 10 \\
7. & Aquadest & ad & ad & ad & ad & ad \\
& & 100 & 100 & 100 & 100 & 100 \\
\hline
\end{tabular}

Alat dan bahan disiapkan. Masing-masing bahan ditimbang sesuai dengan perhitungan bahan. Fase minyak dibuat dengan melebur asam stearat, tambahkan parafin cair, tambahkan setil alkohol di atas hot plate, suhu dipertahankan pada suhu $70^{\circ} \mathrm{C}$. Fase air dibuat dengan melebur TEA dan gliserin diatas hot plate hingga meleleh tambahkan air panas diaduk hingga homogen, suhu dipertahankan $70^{\circ} \mathrm{C}$. Krim dibuat dengan cara menambahkan fase minyak ke dalam fase air. Bila suhu krim sudah mencapai suhu $\pm 45^{\circ} \mathrm{C}$, kemudian ditambahkan ekstrak daun Kaliandra yang sudah diencerkan dengan propilenglikol sambil terus diaduk sampai homogen.

\section{Uji efektivitas antibakteri terhadap Staphylococcus aureus}

Uji efektivitas antibakteri terhadap sediaan krim dilakukan dengan menggunakan metode difusi agar (difusi kirby dan baeur yang dimodifikasi) dengan cara sumuran dengan 2 lapisan media agar dengan pengerjaan lapisan agar yang pertama dibuat dengan menggunakan masing-masing $15 \mathrm{~mL}$ NA ke dalam 3 cawan petri, selanjutnya dibiarkan memadat. Setelah memadat, pada permukaan lapisan dasar ditanam 7 pecandang yang diatur jaraknya agar daerah pengamatan tidak bertumpu. Suspensi bakteri dicampurkan kedalam pembenihan NA. Kemudian dituangkan $10 \mathrm{~mL}$ NA ke media pembenihan. Lapisan agar yang kedua dibuat dengan menggunakan masing-masing $15 \mathrm{~mL}$ NA yang sudah ditambahkan suspensi bakteri ke dalam 3 cawan petri, selanjutnya dibiarkan memadat. Setelah lapisan kedua memadat, pecandang diangkat secara aseptic menggunakan pinset dari masing-masing cawan petri, sehingga 
terbentuk sumur-sumur yang akan digunakan dalam uji antibakteri. Kemudian pada sumur-sumur yang berbeda dimasukan Krim ekstrak daun Kaliandra dengan konsentrasi $2 \%, 3 \%, 4 \%, 5 \%$, dan $6 \%$, kontrol (-) basis krim tanpa ekstrak, kontrol (+) krim gentamicin sebanyak 0,1 g. kemudian diinkubasi pada suhu $35-37^{\circ} \mathrm{C}$ selama 24 jam. Diameter zona hambat yang terbentuk diukur menggunakan mikrometer untuk menentukan efektivitas antibakteri.

\section{Hasil dan Pembahasan}

Hasil identifikasi tanaman daun Kaliandra dilakukan di Laboratorium Biologi Fakultas Matematika dan IImu Pengetahuan Alam Universtas Sam Ratulangi Manado. Identifikasi di lakukan agar mengetahui sampel yang diambil dan di lakukan pengujian adalah sampel yang sesuai yaitu daun Kaliandra.

Proses ekstraksi menggunakan metode ekstraksi cara dingin, yaitu maserasi menggunakan $1600 \mathrm{~mL}$ pelarut etanol 96\%, proses maserasi dilakukan selama 5 hari dan diremaserasi selama 2 hari hingga diperoleh ekstrak kental sebanyak 36,7 g. Rendemen yang diperoleh $9,17 \%$ b/v. Dari hasil ekstrak kental yang diperoleh dilanjutkan untuk membuat krim dengan variasi konsentrasi $2 \%, 3 \%$, 4\%, 5\%, 6\%. Dari ke - 5 konsentrasi dilanjutkan dengan pengujian aktivitas antibakteri.

Hasil pengujian antibakteri dapat dilihat pada tabel 2.

Tabel 2. Hasil Data Pegujian Mikrobiologi Krim Ekstrak Etanol Daun Kaliandra

\begin{tabular}{ccccc}
\hline & \multicolumn{4}{c}{ Diameter daerah hambatan (mm) \pm SD } \\
\cline { 2 - 5 } & $\begin{array}{c}\text { Ulangan } \\
\text { I }\end{array}$ & $\begin{array}{c}\text { Ulangan } \\
\text { II }\end{array}$ & $\begin{array}{c}\text { Ulangan } \\
\text { III }\end{array}$ & Rata-Rata \pm SD \\
\hline $\mathrm{K}(-)$ & 0 & 0 & 0 & $0 \pm 0,00$ \\
\hline $\mathrm{K}(+)$ & 12,00 & 9,78 & 9,05 & $10,27 \pm 1,53$ \\
\hline $\mathrm{FI}$ & 2,55 & 2,75 & 2,55 & $2,61 \pm 0,11$ \\
\hline FII & 3,13 & 3,05 & 2,65 & $2,95 \pm 0,25$ \\
\hline FIII & 3,15 & 3,55 & 3,25 & $3,31 \pm 0,20$ \\
\hline FIV & 3,55 & 3,15 & 3,67 & $3,46 \pm 0,27$ \\
\hline FV & 4,67 & 6,05 & 4,55 & $5,09 \pm 0,88$ \\
\hline
\end{tabular}

$\mathrm{K}(-)$ : Basis krim tanpa ekstrak, $\mathrm{K}(+)$ : Krim Gentamicin, FI: Formulasi sediaan krim ekstrak etanol Daun Kaliandra konsentrasi 2\%, FIl: Formulasi sediaan krim ekstrak etanol Daun Kaliandra konsentrasi 3\%, FIII: Formulasi sediaan krim ekstrak etanol Daun Kaliandra konsentrasi 4\%, FIV: Formulasi sediaan krim ekstrak etanol Daun Kaliandra konsentrasi $5 \%$, FV: Formulasi sediaan krim ekstrak etanol Daun Kaliandra konsentrasi $6 \%$

Hasil pengujian yang didapat dengan konsentrasi 2\%, 3\%, 4\%, 5\%, 6\% menunjukan aktivitas antibakteri dengan adanya zona hambat disekitar sumuran. Diameter zona hambat disekitar sumuran diukur menggunakan jangka sorong dengan cara mengukur secara horizontal dan vertikal kemudian hasil yang didapatkan dikurangi diameter sumuran $7 \mathrm{~mm}$. Krim ekstrak etanol daun Kaliandra konsentrasi 2\% memberikan daya hambat $2,61 \mathrm{~mm}, 3 \%$ memberikan daya hambat 2,95 mm, $4 \%$ memberikan daya hambat 3,31 $\mathrm{mm}, 5 \%$ memberikan daya hambat 3,46 $\mathrm{mm}$, dari hasil ke 4 konsentrasi tersebut dapat dikategorikan memiliki daya hambat yang lemah sedangkan pada konsentrasi $6 \%$ memberikan daya hambat 5,09 $\mathrm{mm}$ dari hasil tersebut dapat dikategorikan memiliki daya hambat yang sedang. kontrol positif memberikn daya hambat $15 \mathrm{~mm}$ dan control negatif tidak memberikan daya hambat karena menghasilkan zona hambat $0 \mathrm{~mm}$. dari hasil tersebut dapat dilihat bahwa krim ekstrak etanol daun Kaliandra dengan konsentrasi 2\%,3\%, 4\%, $5 \%$, dan $6 \%$ bisa menghambat aktivitas bakteri Staphylococcus aureus dengan menjadikan konsentrasi terbesar yaitu $6 \%$ dikarenakan pada konsentrasi $6 \%$ memiliki daya hambat yang paling besar. Zona hambat yang terbentuk karena adanya senyawa antibakteri pada daun Kaliandra. senyawa flavonoid, saponin, dan tannin. Dari hasil yang didapat menunjukkan semakin tinggi konsentrasi sediaan krim maka semakin besar daya hambat yang dihasilkan.

\section{Kesimpulan}

Sediaan krim ekstrak etanol daun Kaliandra menghasilkan daya hambat antibakteri terbesar pada konsentrasi $6 \%$ sebesar 5,09 $\pm 0,88 \mathrm{~mm}$. Dapat disimpulkan bahwa sediaan krim ekstrak etanol daun Kaliandra memiliki efektifitas sebagai krim antibakteri..

\section{Daftar Pustaka}

Edy, H.J., Marchaban, Wahyuono, S., Nugroho, A.E.2016. Formulasi Dan Uji Sterilitas Hidrogel Hebral Ekstrak Etanol Daun Tagetes Erecta L. Pharmacon 5, 9-16.

Jawetz, E., Melnick, J. L., Adelberg, E. A.. 2001. Mikrobiologi Kedokteran, EdisiXXII, diterjemahkan oleh Bagian Mikrobiologi Fakultas Kedokteran. Universitas Airlangga. 205-209. Penerbit Salemba Medika, Jakarta.

Leboffe, MJ., Pierre BE. 2011. A Photographic Atlas for the Microbiology Laboratory. Morton Publishing Company.

Radji, M. 2011. Buku Ajar Mikrobiologi Panduan Mahasiswa Farmasi dan Kedokteran, 107, 118, 201-207, 295, Jakarta, Buku Kedokteran EGC

Roshetko, J.M. 2000. Calliandra calothyrsus di Indonesia. Lokakarya Produksi Benih dan Pemanfaatan Kaliandra, $14-16$ November. International Centre for Research in Agroforestry dan Winrock International, Bogor: 28-32.

Unvala, H.M. 2009. Handbook of Pharmaceutical Excipients, $6^{\text {th }}$ Edition. Pharmaceutical Press. Washington. pp. 155-156.

Utami, N. A. 2017. Uji Daya Hambat Bakteriostatik Ekstrak Tomat (Lycopersicon Esculentum Mill) Terhadap Bakteri Staphylococcus Epidermidis. Fakultas Keguruan dan IImu Pendidikan, Universitas Sanata Dharma, Yogyakarta. 